\title{
The Exploration and Practice of the Development of Green Eco-Urban Areas in Guangzhou International Financial City
}

\begin{abstract}
Active exploration has been carried out to determine a pattern for developing green eco-urban areas in the Starting Area of Guangzhou International Financial City with an emphasis on the core role of comprehensive green arrangement. By comparing and analyzing existing research, development of green technologies at home and abroad, and indicator systems of green urban areas of similar sizes, the builders developed a green ecological indicator system. They proposed a new concept called "district-level indicator" in order to emphasize the importance of classifying indicators according to different project situations. By verifying the indicators for all land parcels and assessing future costs and efficiency, experience accumulated in this project can be beneficial for future green eco-urban area development projects.
\end{abstract}

Keywords: Guangzhou International Financial City, green eco-urban area, indicator system, case verification

\section{A brief introduction to the Starting Area of Guangzhou International Financial City}

The Starting Area of Guangzhou International Financial City is located along the north side of the Pearl River to the east of the Guangzhou downtown area. It is adjacent to the CBD of the Pearl River New Town area and faces the Pazhou International Exhibition Center across the Pearl River, constituting the core functional area and pioneering development area of the Financial City. The Starting Area covers a total area of $1.32 \mathrm{~km}^{2}$. The total planned building area covers about 4,980,000 $\mathrm{m}^{2}$, including an underground

Manuscript received July 6, 2015; accepted November 7, 2015

Jia-meng Chen

Guangzhou Administration Office of Major Public Construction Projects, Guangzhou 500006, China

Peng Liu $(\varangle)$

Shenzhen Institute of Building Research Co., Shenzhen 518049, China Email: 870025184@qq.com building area of about $530,000 \mathrm{~m}^{2}$. Functions in this area cover offices, hotels, business, culture and entertainment, and residential buildings. The area accommodates a planned working population of 178,000 .

In accordance with the development requirements of new urbanization featuring a "low-carbon economy, an intelligent city, and happy lifestyles" and adopting a global perspective, this project plans to build the Starting Area of Guangzhou International Financial City into a leading financial cluster in China. Set in Guangzhou, relying on the Pearl River Delta, and facing Southeast Asia, this project aims to build a best practice area of new urbanization, a leading financial cluster in China, a Central Activities Zone (CAZ) with local characteristics of the South of the Five Ridges region, and a world-class ideal eco-urban area. Figure 1 shows the aerial view of this project.

\section{Implementation philosophy of the green eco-urban area}

The general purpose of the Starting Area of Guangzhou International Financial City is to embody the characteristics of green, ecological, energy efficient, and environmental friendliness throughout the whole construction process. To achieve the above purpose, one feasible approach is to build a quantifiable green building technology indicator system and monitor all buildings based on this indicator system to form scale effect, so that the overall green construction costs can be reduced while the demonstrable green effects can be reinforced.

To build a quantifiable green building technology indicator system, the following four questions need to be addressed:

1) What content does the green building technology indicator macro system in the entire area include?

2) How is the green building technology indicator macro system allocated to each land parcel?

3) How to select appropriate green building technology in order to meet the green building technology indicators allocated to each land parcel and to take the local 


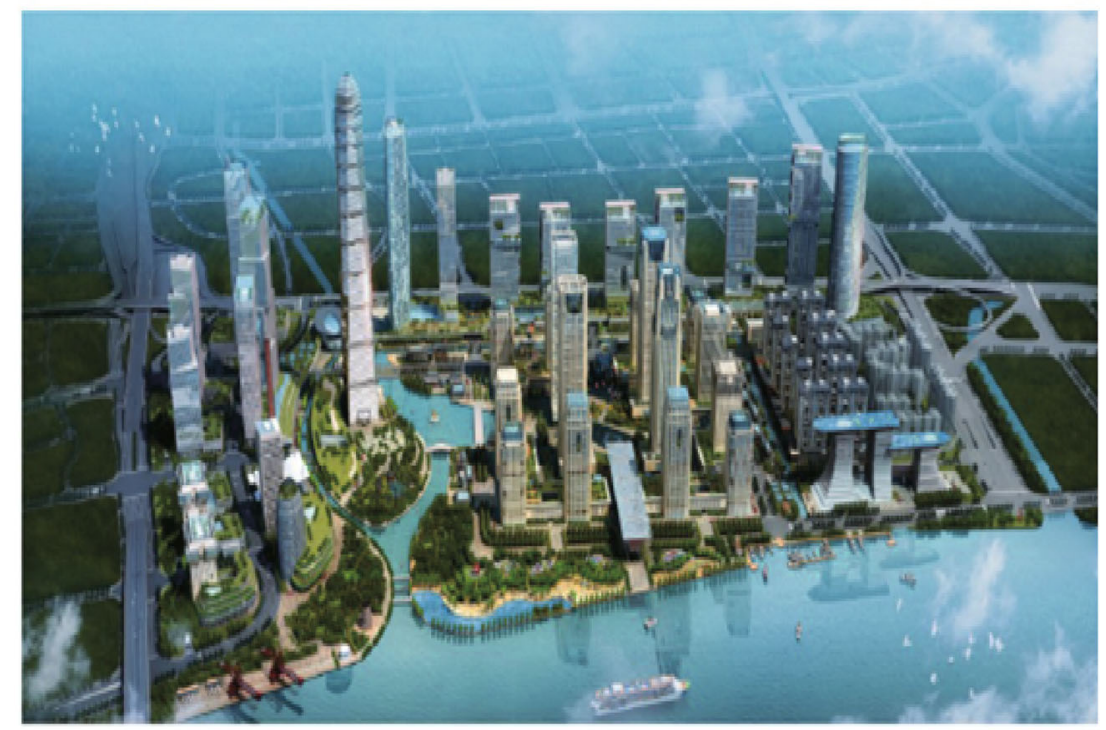

Figure 1. Aerial view of the Starting Area of Guangzhou International Financial City.

conditions into full consideration?

4) What are the benefits of the green building technology indicator system?

Figure 2 shows the implementation approach for the green eco-urban area in the Starting Area of Guangzhou International Financial City.

\section{Exploration of the indicator system for the Green Eco-Urban Area}

To ensure that the green technology indicator macro system is complete, advanced, and in line with current science, this project studies the existing project documentation, green building technology advances at home and abroad, and green technology indicator systems for urban areas of similar size. By analyzing the existing project documentation, we can determine the green ecological technology indicators already covered in the project from the regulatory plans and related research results to ensure that the indicators are complete (for example, the regulatory plan of each land parcel has mandatory requirements regarding the field comprehensive runoff coefficient and the green area ratio of the skirt building roof). Based on this, we have studied the updates of green building technologies and standards in China, selected green technological measures suitable for the Guangzhou climate and this project's functions, supplemented with additional green ecological indicators to ensure that the technical measures are advanced. Finally, we compare the green ecological indicators of this project with those of the districts of similar size (such as Shenzhen Qianhai Planned Area, Technology Ecological Park in Shenzhen Bay, Chongqing Yuelai Ecological Urban Area, and Xiamen
Technology Innovation Park), so as to determine the indicator system for the green eco-urban area of the Starting Area of Guangzhou International Financial City (as shown in Table 1).

\section{Indicator allocation, verification, and cost-efficiency analysis of the green eco-urban area}

\subsection{Allocation of ecological indicators}

To avoid previous problems such as grandiose macro indicators, failure to highlight characteristics of land parcels, and unclear area specialties, this project classifies and allocates indicators into three levels (area, district, and land parcel) according to the general objective, and sets preliminary indicator values based on the fundamental conditions of each land parcel. Technologies for the area and land parcel levels must be implemented for all land parcels. Land parcels differ from each other mainly in technology indicators at the district level. District-level indicators are set to avoid blindly investing the difficult and costly technologies into all land parcels with an emphasis on technology characteristics and highlights of each land parcel. Perform the following three steps to set such indicators:

Step 1: Divide districts based on the regulatory plan design concept of the Starting Area of Guangzhou International Financial City.

The regulatory plan generally divides the Starting Area into five parts: special living district, financial office district, waterfront leisure district, HQ office district, and comprehensive commercial district. Due to functional 


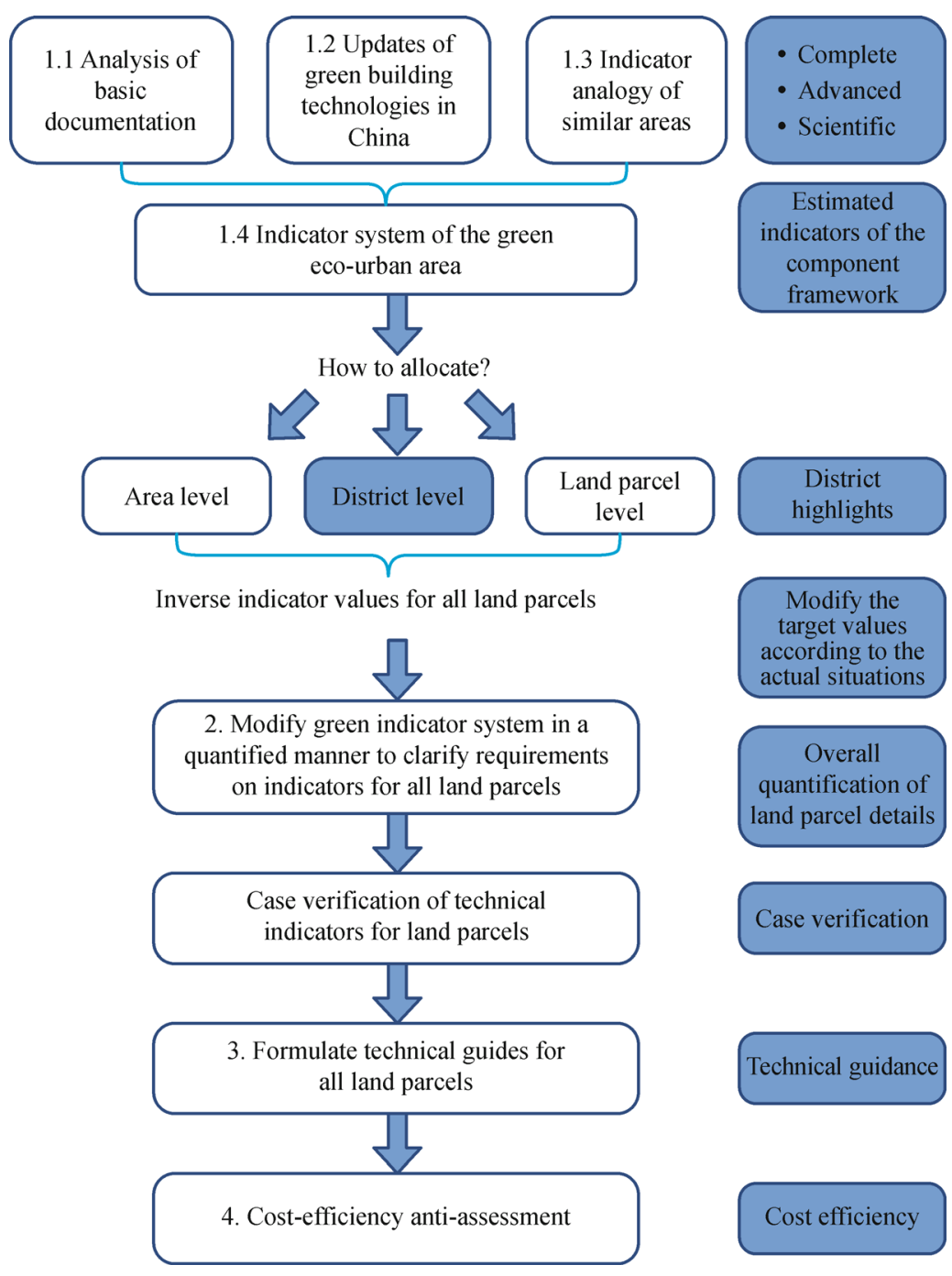

Figure 2. Implementation approach for the green eco-urban area in the Starting Area of Guangzhou International Financial City.

similarity and geographical connection, we combine the waterfront leisure district with the financial office district, and thereby the Starting Area is divided into four districts geographically.

Step 2: Analyze problems and external conditions of each district.

Figure 3 shows the external conditions, problems, and suggestions for each district.

Step 3: Clarify green indicator requirements for each district.

Comprehensively analyze the problems and conditions of each district according to step 2, provide improvement suggestions accordingly, and clarify green indicators for each district. For details, see Figure 4.

The indicator "renewable energy utilization ratio" is used as an example to describe how an indicator is generated.

For this project, it is suitable to adopt solar energy as the renewable energy. According to the above-mentioned district division, solar energy should be used in the special living district and financial office district, where the residential buildings adopt solar thermal power while others adopt solar photovoltaic power.

However, considering the high cost of implementing the renewable energy utilization system, when formulating technical requirements for all land parcels, we have to exclude the land parcels that are not suitable for solar power to ensure efficient operation of this technological measure and to reach the star-standard target for green buildings in each land parcel. Specific cases include the following (Figure 5):

1. Some land parcels, such as AT090938 and AT090940, are not suitable for solar energy utilization, because the overall efficiency of the solar system is affected by building shading.

2. Some land parcels such as AT091008 are long and narrow and stretch from east to west, and thereby are not suitable for solar panel pavement.

3. For land parcels with low star ratings (star 1), the 
Table 1

Indicator System for the Green Eco-Urban Area of the Starting Area of Guangzhou International Financial City

\begin{tabular}{|c|c|c|}
\hline Type & Indicator name & Indicator value \\
\hline Land conservation & Underground space usage ratio & $\geqslant 1.6$ \\
\hline \multirow[t]{5}{*}{ Energy conservation } & Renewable energy utilization ratio & $\geqslant 0.4 \%$ \\
\hline & Energy conservation ratio of the building envelope & $\begin{array}{c}\text { Public building: Star } 1 \geqslant 50 \% \text {; Star } 2 \geqslant 51.5 \% \text {; Star } 3 \geqslant 52.5 \% \\
\text { Residential building: } \geqslant 50 \%\end{array}$ \\
\hline & Building lighting power density & Target value \\
\hline & $\begin{array}{c}\text { Efficiency enhancement of cold/hot sources in the heater and air } \\
\text { conditioner }\end{array}$ & $\geqslant 6 \%$ \\
\hline & Coverage of the building energy consumption monitoring system & Public building: $100 \%$ \\
\hline \multirow[t]{5}{*}{ Water conservation } & Nontraditional water resource utilization ratio & $\geqslant 5.5 \%$ \\
\hline & Field comprehensive runoff coefficient & $\leqslant 0.49$ \\
\hline & LID construction ratio & $\geqslant 25 \%$ \\
\hline & Popularity of water-saving instruments & $100 \%$ \\
\hline & Coverage of water-saving irrigation & $100 \%$ \\
\hline Material conservation & High-strength steel utilization ratio & $\geqslant 70 \%$ \\
\hline \multirow[t]{8}{*}{ Environment quality } & Green volume ratio & $\geqslant 0.85$ \\
\hline & Compliance rate of environmental noises & $\geqslant 90 \%$ \\
\hline & Landscaping ratio of the skirt building surface & $\geqslant 40 \%$ \\
\hline & Length ratio of sidewalk shade to sidewalk shelter & $\geqslant 5 \%$ \\
\hline & Field ventilation suitability in the summer & $\geqslant 80 \%$ \\
\hline & Compliance rate of the daylighting on the ground floor & $\geqslant 4.5 \%$ \\
\hline & Indoor background noise of the building & $\begin{array}{c}\text { Land parcels on both sides of the backbone road on the ground } \\
\text { average value of the lower limit and the higher standard } \\
\text { Others: higher standard value }\end{array}$ \\
\hline & Percentage of prioritized parking spaces & $\geqslant 10 \%$ \\
\hline
\end{tabular}

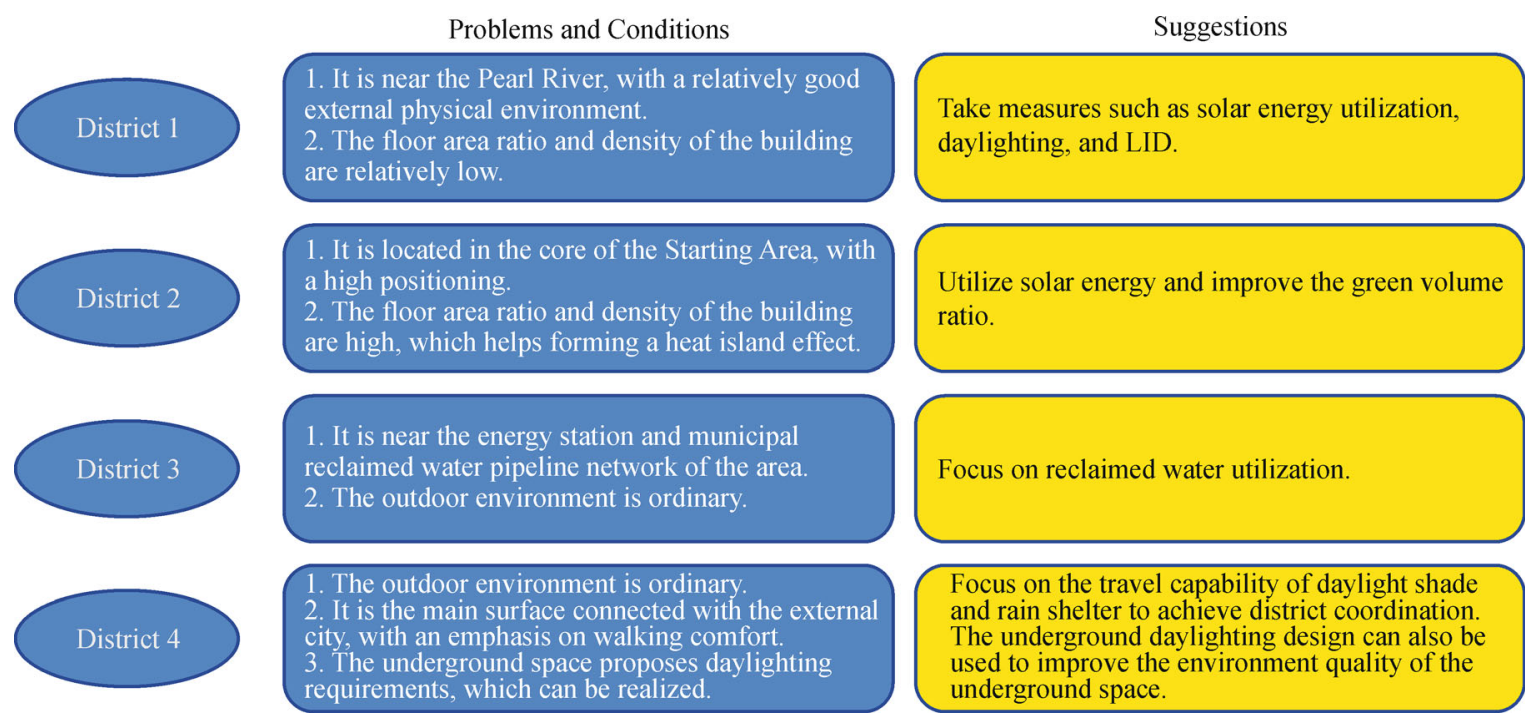

Figure 3. External conditions, problems, and suggestions for each district in the Starting Area of Guangzhou International Financial City. 


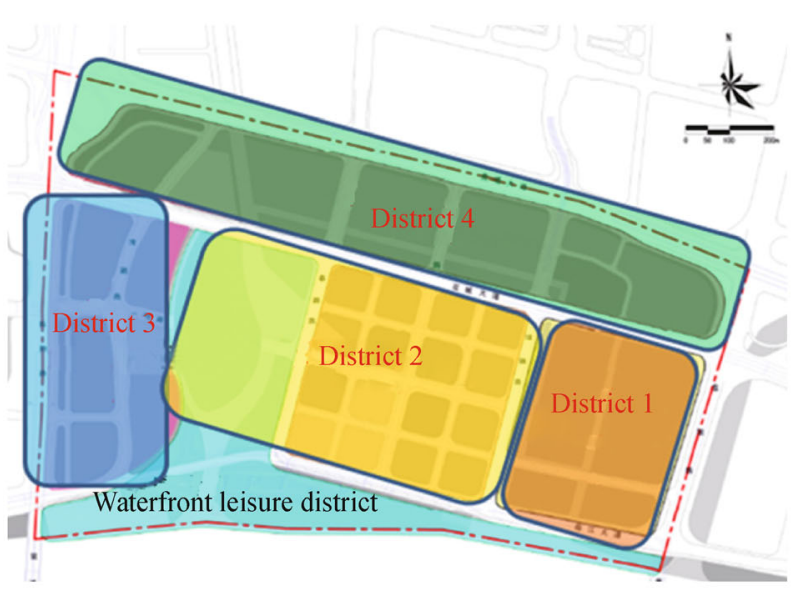

District 1

1. Solar energy utilization (renewable energy utilization ratio) 2. Underground daylighting (compliance rate of daylighting on the ground floor)

3. LID (LID construction ratio)

\section{District 2}

1. Solar energy utilization (renewable energy utilization ratio)

2. Mitigate the heat island effect (green volume ratio)

\section{District 3}

1. Reclaimed water utilization (untraditional water resource utilization ratio)

\section{District 4}

1.Comfortable travel outdoors (length ratio of sidewalk

shade to sidewalk shelter)

2. Underground daylighting (compliance rate of daylighting on the ground floor)

Figure 4. Green technology indicators for each district in the Starting Area of Guangzhou International Financial City.

renewable energy utilization technology is not required when comprehensively considering the cost performance ratio of the costs and technologies.

Figure 6 shows the land parcels with no requirements related to the "renewable energy utilization ratio" indicator in the special living district and financial office district. For other land parcels, renewable energy utilization measures should be taken.

After calculation, the renewable energy utilization is $0.381 \%$ for the field. To highlight the advancement of the Starting Area of the Guangzhou International Financial City, the technical standard of renewable energy utilization should be equal to or greater than $0.4 \%$ for this project.

\subsection{Example verification of ecological indicators}

The Guangzhou International Financial City project has 20 indicators in total for green eco-urban area construction. Among these indicators, 14 are technological measures of the area and land parcel levels, and these 14 technological measures should be implemented for all land parcels. For the remaining 6 district-level indicators, specific technical indicator requirements should be determined according to the corresponding district and actual project characteristics of each land parcel. To ensure that the work approach is in line with current science, we used the AT090908 land parcel as an example to conduct case verification, reviewed the case based on the indicator and design conditions, and provided suggestions. The details are shown in Table 2 .

According to the case verification, although some indicators of AT090908 do not meet the requirements or cannot be determined, they can be improved in subsequent designs. That is, the working approaches of the indicator system for the green eco-urban area and values specified for each land parcel are basically in line with current science and preliminarily feasible.

\subsection{Cost-efficiency analysis}

\subsubsection{Cost analysis}

If the Starting Area of Guangzhou International Financial City is constructed according to the technical indicators (20 in total) of the green eco-urban area, the total incremental costs are about CNY 163,000,000 and the incremental costs for a unit of the building area are about CNY 33.90 per square meters. For details, see Table 3.

\subsubsection{Efficiency analysis}

\section{1) Resourceintensification efficiency}

After the indicators of the green eco-urban area are implemented, it is estimated that $106,000 \mathrm{~m}^{2}$ of construction land can be saved; 27,908,000 kWh of energy consumption can be saved per year; 1,180,200 tons of municipal tap water can be saved; operation expenses of CNY 33,896,000 can be saved per year; the static investment payback period is about 4.8 years. For details, see Table 4.

2) Environmentally friendly efficiency

With this project, the sewage discharge is reduced by about $1,180,000$ tons per year; the rainfall emission is reduced by about 600,000 tons per year; the energy saved per year is $27,908,000 \mathrm{kWh}$; the $\mathrm{CO}_{2}$ emission reduced per year is 8470.5 tons. Table 5 and Table 6 list the environmentally friendly efficiency and other areas of increased efficiency respectively. 


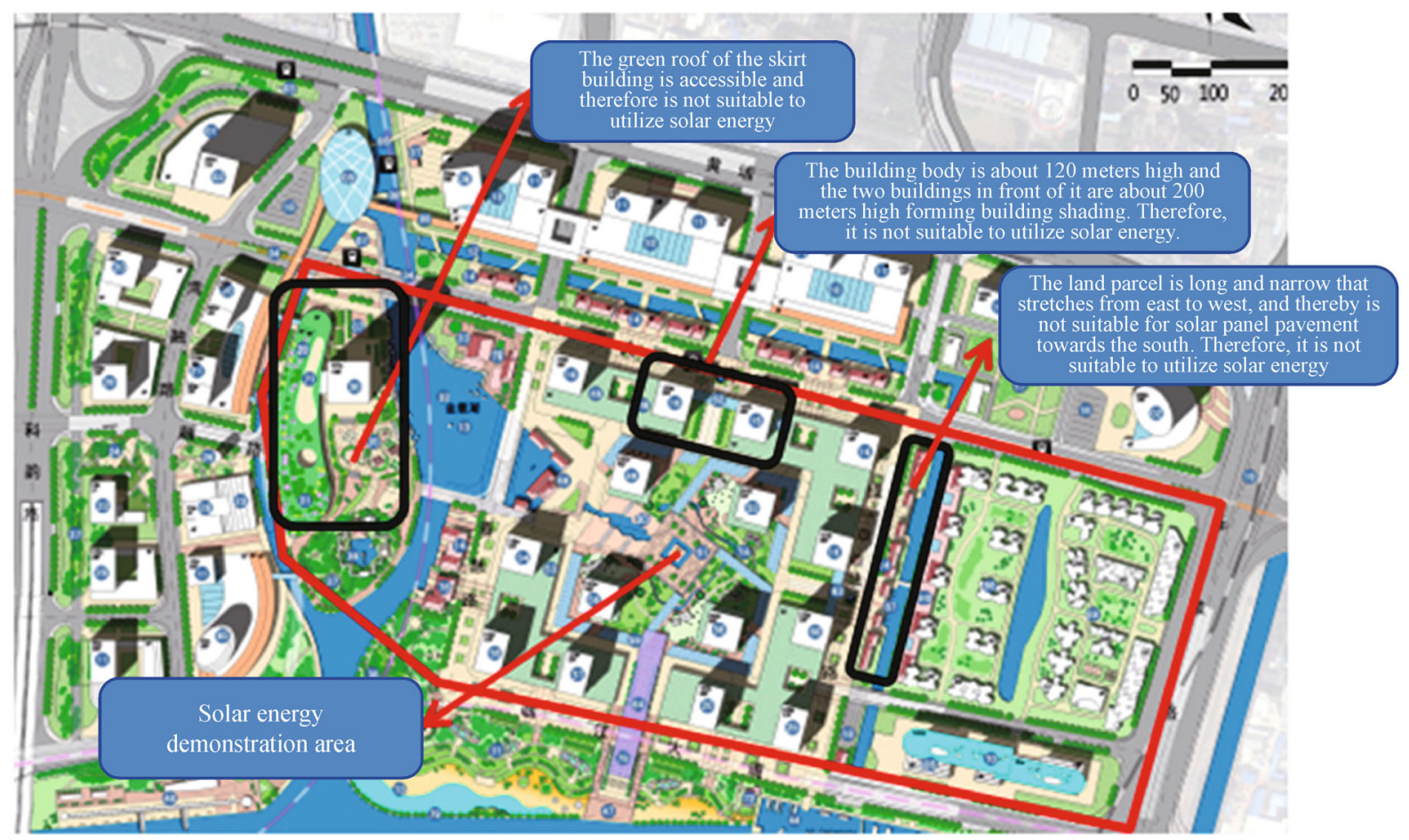

Figure 5. Centralized district for renewable resource utilization (land parcels are not suitable for such utilization).

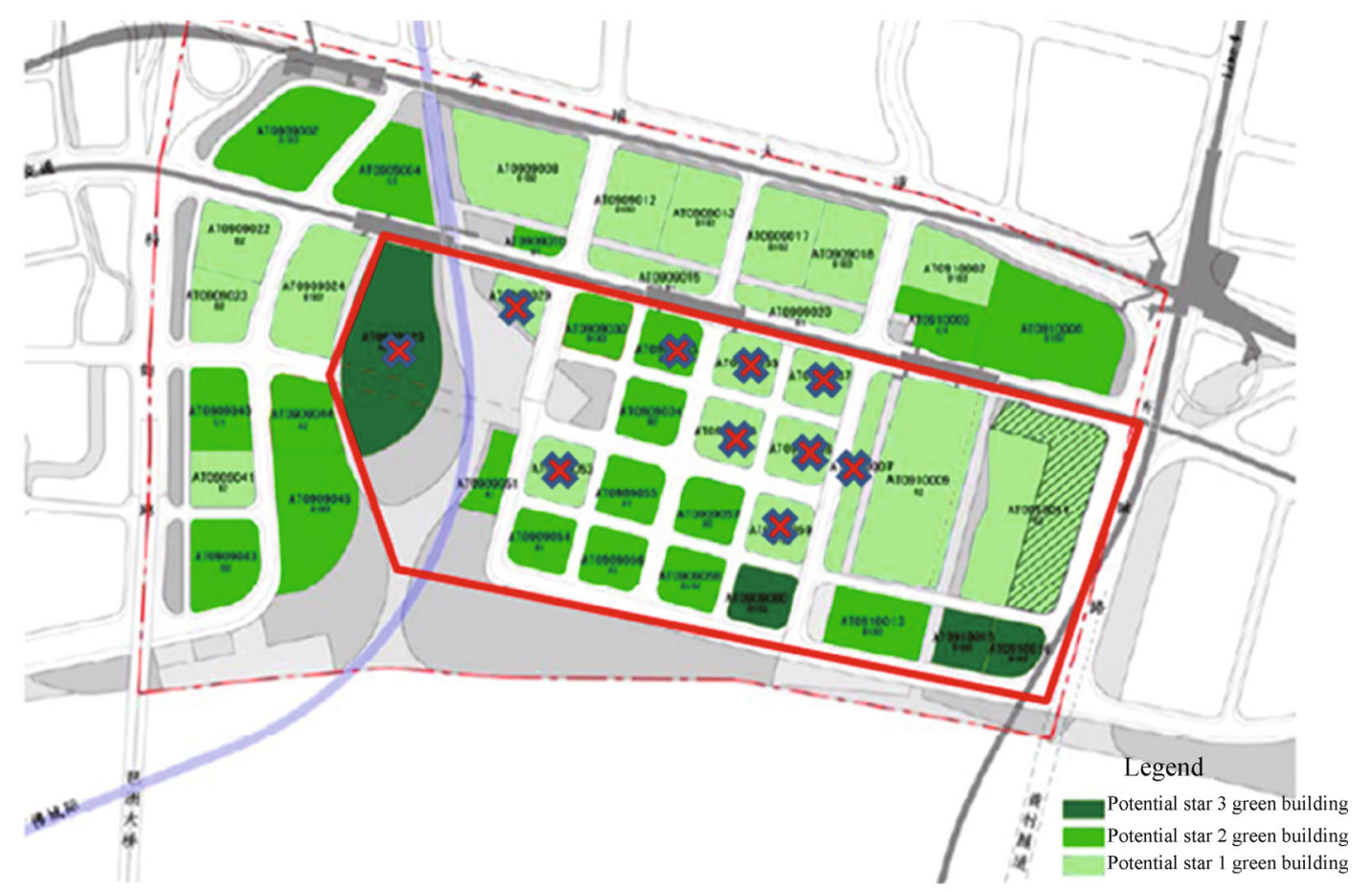

Figure 6. Renewable energy utilization in the central district (land parcels with red crosses are not suitable). 


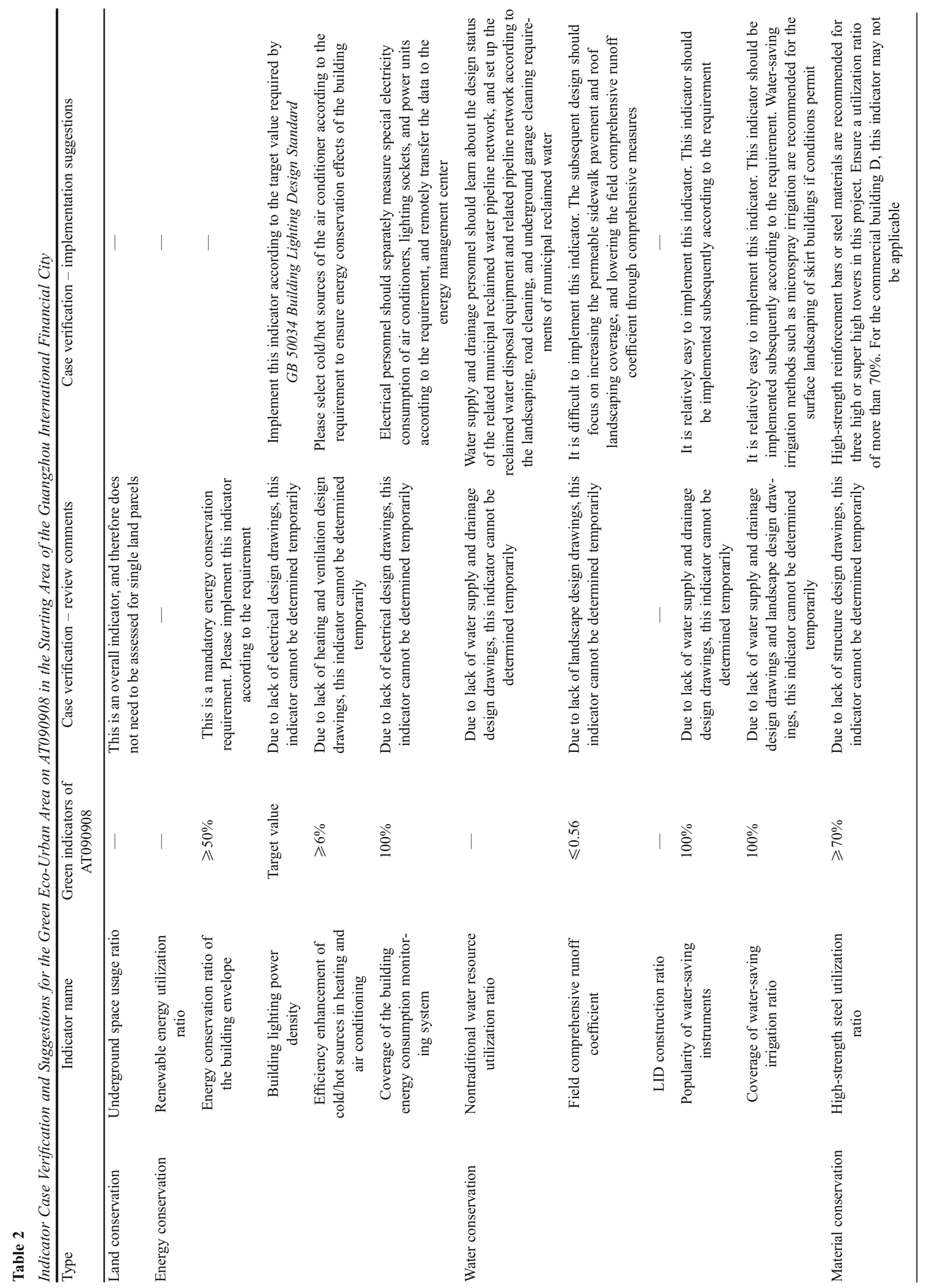




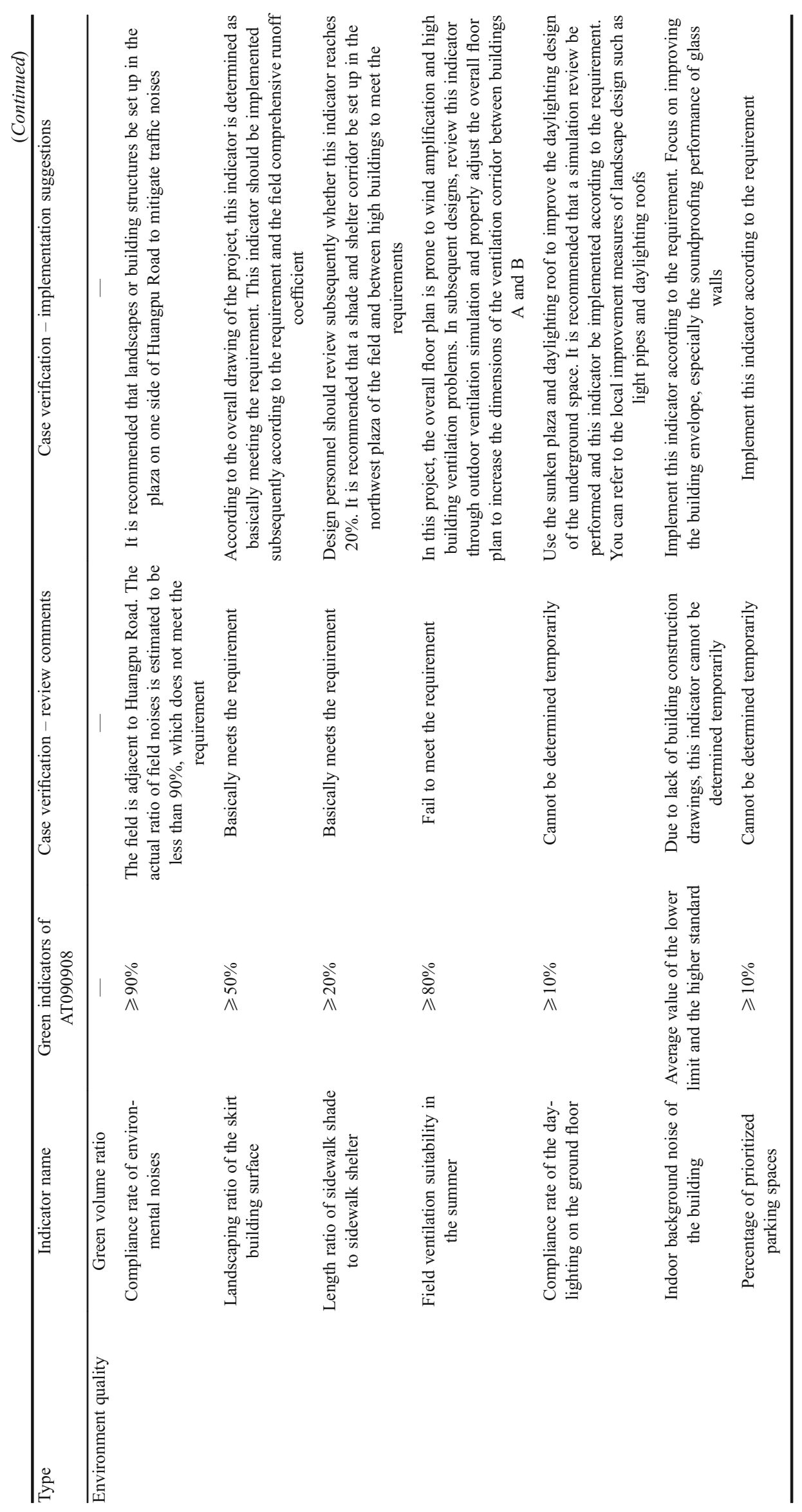


Table 3

Estimation of the Incremental Costs for Constructing the Green Eeco-Urban Area in the Starting Area of Guangzhou International Financial City Type Indicator name Indicator value Incremental costs/ (CNY 10,000)

\begin{tabular}{|c|c|c|c|}
\hline Land conservation & Underground space usage ratio & $\geqslant 1.6$ & - \\
\hline \multirow[t]{5}{*}{ Energy conservation } & Renewable energy utilization ratio & $\geqslant 0.40 \%$ & $\begin{array}{l}\text { Photovoltaic: } 3553 \\
\text { Thermal: } 750\end{array}$ \\
\hline & $\begin{array}{c}\text { Energy conservation ratio of the building } \\
\text { envelope }\end{array}$ & $\begin{array}{c}\text { Public buildings: Star } 1 \geqslant 50 \% \text {; Star } 2 \geqslant 51.5 \% \text {; } \\
\text { Star } 3 \geqslant 52.5 \% \text {; Residential buildings: } \geqslant 50 \%\end{array}$ & 2708 \\
\hline & Building lighting power density & Target value & 2400 \\
\hline & $\begin{array}{l}\text { Efficiency enhancement of cold/hot sources } \\
\text { in heating and air conditioning }\end{array}$ & $\geqslant 6 \%$ & 5760 \\
\hline & $\begin{array}{l}\text { Coverage of the building energy consump- } \\
\text { tion monitoring system }\end{array}$ & Public buildings: $100 \%$ & 410 \\
\hline \multirow[t]{5}{*}{ Water conservation } & $\begin{array}{c}\text { Nontraditional water resource utilization } \\
\text { ratio }\end{array}$ & $\geqslant 5.5 \%$ & 346 \\
\hline & Field comprehensive runoff coefficient & $\leqslant 0.49$ & - \\
\hline & LID construction ratio & $\geqslant 25 \%$ & - \\
\hline & Popularity of water-saving instruments & $100 \%$ & - \\
\hline & Coverage of water-saving irrigation & $100 \%$ & 128 \\
\hline Material conservation & High-strength steel utilization ratio & $\geqslant 70 \%$ & - \\
\hline \multirow[t]{8}{*}{ Environment quality } & Green volume ratio & $\geqslant 0.85$ & - \\
\hline & Compliance rate of environmental noises & $\geqslant 90 \%$ & - \\
\hline & $\begin{array}{c}\text { Landscaping ratio of the skirt building } \\
\text { surface }\end{array}$ & $\geqslant 40 \%$ & - \\
\hline & $\begin{array}{c}\text { Length ratio of sidewalk shade to sidewalk } \\
\text { shelter }\end{array}$ & $\geqslant 5 \%$ & - \\
\hline & Field ventilation suitability in the summer & $\geqslant 80 \%$ & - \\
\hline & $\begin{array}{l}\text { Compliance rate of daylighting on the } \\
\text { ground floor }\end{array}$ & $\geqslant 4.5 \%$ & 216 \\
\hline & Indoor background noise of the buildings & $\begin{array}{c}\text { Land on both sides of the backbone road on } \\
\text { the ground: average value of the lower limit } \\
\text { and the higher standard; Others: higher standard } \\
\text { value }\end{array}$ & - \\
\hline & Percentage of prioritized parking spaces & $\geqslant 10 \%$ & - \\
\hline
\end{tabular}

Table 4

Resource Intensification Efficiency of the Project

\begin{tabular}{|c|c|c|c|}
\hline Type & Indicator name & Indicator value & Resources intensification efficiency \\
\hline Land conservation & Underground space usage ratio & $\geqslant 1.6$ & Saving a land area of $106,000 \mathrm{~m}^{2}$ \\
\hline \multirow[t]{4}{*}{ Energy conservation } & Renewable energy utilization ratio & $\geqslant 0.40 \%$ & Saving $1,877,000 \mathrm{kWh}$ per year \\
\hline & $\begin{array}{l}\text { Energy conservation ratio of the building } \\
\text { envelope }\end{array}$ & $\begin{array}{c}\text { Public buildings: Star } 1 \geqslant 50 \% ; \text { Star } \\
2 \geqslant 51.5 \% ; \text { Star } 3 \geqslant 52.5 \% ; \text { Residential } \\
\text { buildings: } \geqslant 50 \%\end{array}$ & Saving $3,270,000 \mathrm{kWh}$ per year \\
\hline & Building lighting power density & Target value & Saving $14,016,000 \mathrm{kWh}$ per year \\
\hline & $\begin{array}{l}\text { Efficiency enhancement of cold/hot } \\
\text { sources in heating and air conditioning }\end{array}$ & $\geqslant 6 \%$ & Saving $8,640,000 \mathrm{kWh}$ per year \\
\hline \multirow[t]{2}{*}{ Water conservation } & $\begin{array}{c}\text { Nontraditional water resource utilization } \\
\text { ratio }\end{array}$ & $\geqslant 5.5 \%$ & Saving 408,200 tons of water per year \\
\hline & Popularity of water-saving instruments & $100 \%$ & Saving 772,000 tons of water per year \\
\hline Environment quality & $\begin{array}{c}\text { Compliance rate of the daylighting on the } \\
\text { ground floor }\end{array}$ & $\geqslant 4.5 \%$ & Saving $105,000 \mathrm{kWh}$ per year \\
\hline
\end{tabular}


Table 5

Environment Friendly Efficiency

\begin{tabular}{lcccc}
\hline Energy saved per year/kWh & $\begin{array}{c}\text { Standard coal saved per } \\
\text { year/ton }\end{array}$ & $\begin{array}{c}\mathrm{CO}_{2} \text { emission reduced per year/ } \\
\text { ton }\end{array}$ & $\begin{array}{c}\mathrm{SO}_{2} \text { emission reduced } \\
\text { per year/ton }\end{array}$ & $\begin{array}{c}\text { Dust emission reduced per } \\
\text { year/ton }\end{array}$ \\
\hline $27,908,000$ & $34,299,000$ & 8470.5 & 68.7 & 33.9 \\
\hline
\end{tabular}

Table 6

Other Efficiency

\begin{tabular}{|c|c|c|c|}
\hline Type & Indicator name & Indicator value & Descriptions of other efficiency \\
\hline \multirow[t]{2}{*}{ Water conservation } & $\begin{array}{l}\text { Field comprehensive runoff } \\
\text { coefficient }\end{array}$ & $\leqslant 0.49$ & $\begin{array}{l}\text { More than a half the rainfall runoff volume can be reduced. This efficiently } \\
\text { reduces the peak discharge of rainfall drainage, relieves municipal drainage } \\
\text { pressure, increases the water retention properties of the field, and reduces the } \\
\text { heat island magnitude of the area }\end{array}$ \\
\hline & LID construction ratio & $\geqslant 25 \%$ & $\begin{array}{l}\text { Technical measures can be taken to increase the rainfall infiltration } \\
\text { such as field landscaping and permeable pavements }\end{array}$ \\
\hline \multirow[t]{7}{*}{ Environment quality } & Green volume ratio & $\geqslant 0.85$ & $\begin{array}{l}\text { The green area ratio of equivalent ground cover plants is about } 85 \% \text {, } \\
\text { creating more green space and volume in a limited space }\end{array}$ \\
\hline & $\begin{array}{l}\text { Compliance rate of environ- } \\
\text { mental noises }\end{array}$ & $\geqslant 90 \%$ & $\begin{array}{l}\text { This ensures quietness and comfort for main personnel in the outdoor } \\
\text { areas of the land parcel }\end{array}$ \\
\hline & $\begin{array}{l}\text { Landscaping ratio of the skirt } \\
\text { building surface }\end{array}$ & $\geqslant 40 \%$ & $\begin{array}{l}\text { This efficiently improves thermal comfort of the skirt building roof and } \\
\text { reduces temperatures of interior roof surfaces by } 3^{\circ} \mathrm{C} \text { to } 5^{\circ} \mathrm{C}\end{array}$ \\
\hline & $\begin{array}{l}\text { Length ratio of sidewalk } \\
\text { shade to sidewalk shelter }\end{array}$ & $\geqslant 5 \%$ & $\begin{array}{l}\text { This provides a barrier-free travel space with daylight shade and shelter } \\
\text { from rain, improving the comfort level of outdoor activities }\end{array}$ \\
\hline & $\begin{array}{l}\text { Field ventilation suitability in } \\
\text { the summer }\end{array}$ & $\geqslant 80 \%$ & $\begin{array}{c}\text { This ensures that over } 80 \% \text { of the occupied area outdoors is ventilated } \\
\text { and that people will feel comfortable }\end{array}$ \\
\hline & $\begin{array}{l}\text { Indoor background noise } \\
\text { of the buildings }\end{array}$ & $\begin{array}{l}\text { Land on both sides of } \\
\text { the backbone road on the } \\
\text { ground: average value of } \\
\text { the lower limit and the } \\
\text { higher standard; Others: } \\
\text { higher standard value }\end{array}$ & $\begin{array}{l}\text { This can create a comfortable and quiet indoor environment with } \\
\text { reference to the surrounding environment }\end{array}$ \\
\hline & $\begin{array}{l}\text { Percentage of prioritized } \\
\text { parking spaces }\end{array}$ & $\geqslant 10 \%$ & $\begin{array}{l}\text { This can promote the usage of small-displacement or new-energy vehicles, } \\
\text { which contributes to urban traffic emission reduction }\end{array}$ \\
\hline
\end{tabular}

\section{Conclusions}

The green ecological civilization construction pattern is an inevitable choice for new urbanization in China. The green eco-urban area indicator system for the Starting Area of Guangzhou International Financial City has been researched based on a full understanding of the local conditions and resources. Taking the area's development purpose into consideration, we have formulated a green eco-urban area indicator macro system for the Starting Area and innovatively divided technical indicators into three levels: area, district, and land parcel. As for district-level indicators, indicator policies can be formulated according to the external conditions and requirements of each corresponding area, thereby achieving consistency between the advancement of the overall green indicators and the feasibility of green indicators for each land parcel. 